\title{
Postharvest effects of acetaldehyde vapour on ripening-related enzyme activity in avocado fruit
}

\author{
Edna Pesis *, Debora Faiman, Sasson Dori \\ Department of Postharvest Science of Fresh Produce, Agricultural Research Organization, The Volcani Center, P.O. Box 6, \\ Bet Dagan, 50250, Israel
}

Received 10 May 1997; accepted 3 February 1998

\begin{abstract}
Exogenous application of acetaldehyde (AA) vapour to whole or half-peeled avocado fruits (Persea americana cv. 'Fuerte'), prior to storage, inhibited fruit ripening. This inhibition was characterized by a delay in fruit softening and a reduction in ethylene production. Activities of the cell wall depolymerizing enzymes polygalacturonase (PG), $\beta$-galactosidase ( $\beta$-GAL) and endoglucanase $(\mathrm{Cx})$, and of 1-aminocyclopropane-1-carboxylic acid oxidase (ACC oxidase), were reduced immediately after treatment. AA-treated fruit had reduced ethylene production and ACC oxidase activity, both in vivo and in vitro. Levels of total free sulfhydryl (SH) group compounds increased in AA-treated fruit, but diminished in untreated fruit. AA treatment inhibited fruit pulp oxidation, while untreated control fruits oxidized and became brown. Application of AA to a PG reaction mixture reduced PG activity on sodium polypectate. Pre-incubation of the substrate with AA did not result in reduced activity. Attempts to detect AA-bound proteins in AA-treated fruits were unsuccessful. (C) 1998 Elsevier Science B.V. All rights reserved.
\end{abstract}

Keywords: Persea americana; ACC; Ethylene; $\beta$-Galactosidase; Endoglucanase; Polygalacturonase; Sulfhydryl groups

\section{Introduction}

Acetaldehyde (AA) and ethanol are two products of anaerobic respiration in fruits; they accumulate during ripening, contributing to fruit aroma (Fidler, 1968), and are capable of retarding senescence and inhibiting ethylene production in plants. AA

\footnotetext{
* Corresponding author. Tel.: + 9723 9683612; fax: + 972 3 9683622; e-mail: vtedna@volcani.agri.gov.il
}

inhibited fruit softening associated with reduced water-soluble pectin in peaches (Lurie and Pesis, 1992), and PG activity in tomato (Pesis and Marinansky, 1993). In grapes, which are nonclimacteric fruits, but still produce ethylene, AA inhibited ethylene production with and without addition of ACC (Pesis and Marinansky, 1992). Recently, it has been demonstrated that AA is the agent responsible for ethanol-induced ripening inhibition in tomato fruits (Beaulieu et al., 1997). 
AA is a very reactive compound, capable of binding covalently to amino groups of proteins to form a Schiff base (Mauch et al., 1986; Perata et al., 1992). However, it seems that the AA molecule cannot easily penetrate the fruit epidermis; in tomato and grape, vapour penetration is mainly through the stem scar (Pesis and Frenkel, 1989; Pesis and Marinansky, 1993). In mango, in which the stem area is relatively blocked, AA vapour could not easily penetrate via the cuticle and there was no influence on ripening (Burdon et al., 1994). However, in half-peeled mango fruit, AA penetrated the flesh and caused inhibition of ethylene production and ACC oxidase activity (Burdon et al., 1996).

In avocado, anaerobiosis shock, which induces endogenous AA and ethanol production during treatment, reduced chilling injury symptoms, fruit softening, and ethylene production at $2{ }^{\circ} \mathrm{C}$; it also increased levels of free $\mathrm{SH}$ group compounds, which might account for the chilling injury reduction (Pesis et al., 1994). Exposing whole avocado fruit to $80 \%$ ethanol-saturated air for 4 days delayed ripening, the delay being expressed as firmer fruit and lower $\mathrm{CO}_{2}$ and ethylene production (Ritenour et al., 1997). The objective of the present work was to characterize the effect of exogenous application of AA on the activity of selected enzymes involved in regulating fruit softening and ethylene production during avocado ripening.

\section{Materials and methods}

\subsection{Fruit material}

Mature avocado (Persea americana cv. 'Fuerte') fruits (dry matter 25-30\%) were harvested in the central area of Israel and treated the same day of harvesting. In some experiments, whole avocado fruits were treated with AA vapour; in others, half of the entire fruit surface was exposed by removing 1-2 $\mathrm{mm}$ of the outer skin layer with a commercial peeler (Fig. 4), thus eliminating the problem of vapour penetration (Burdon et al., 1996). Fruits were treated with AA immediately after peeling.

\subsection{AA treatment of fruit}

Application of AA vapour to whole fruits enclosed in jars was performed by flushing air over liquid AA. Different AA concentrations were achieved by restricting flow of the AA source through a series of glass capillaries (Pesis and Frenkel, 1989). Fruits were enclosed in five 20-1 glass jars (20 fruits in each) and exposed to a flow of AA vapour in humidified air at a rate of $400 \mathrm{ml}$ $\min ^{-1}$ at $17^{\circ} \mathrm{C}$. Whole fruits were exposed to relatively low AA levels for $24 \mathrm{~h}$. The lowest level applied was 500 ppm AA (average) and the highest 1500 ppm AA (average). The half-peeled fruits were treated with an average concentration of $0.5 \% \mathrm{AA}$, starting at $0.7 \% \mathrm{AA}$ and decreasing to $0.3 \%$ after $18 \mathrm{~h}$, which was the last hour of treatment. The reduction in AA concentration during treatment was due to the evaporation of AA from the AA-water solution, which changed the AA vapour pressure, giving lower AA concentrations in the air stream. Several times during the treatment, AA concentrations were determined by gas chromatography (GC). A $1 \mathrm{ml}$ headspace gas sample was injected into a $2 \mathrm{~m}$ stainless steel column with $10 \%$ Carbowax 20M, flame ionization detector at $180^{\circ} \mathrm{C}, \mathrm{N}_{2}$ as carrier gas, injection temperature of $100^{\circ} \mathrm{C}$, and oven temperature of $80^{\circ} \mathrm{C}$.

After AA application, jars were ventilated with humid air for $24 \mathrm{~h}$. In one case - measurement of endogenous levels of AA and ethanol-the jars were opened after $4 \mathrm{~h}$ of air ventilation. Control fruits (whole or half-peeled) were ventilated with humid air at $17^{\circ} \mathrm{C}$ for the same length of time as the treated ones. At the end of the treatment, all fruits were transferred to cardboard boxes at $17^{\circ} \mathrm{C}$ until required for further examination.

\subsection{Measurements of firmness and endogenous $A A$ and ethanol}

Fruit firmness was measured on two pared sides of each fruit, whole or half-peeled, using an electronic penetrometer (Chatillon, New York, NY) with a $6.5-\mathrm{mm}$ conical tip.

Endogenous AA and ethanol levels were measured in pulp discs in situ. For these measure- 
ments, jars were opened $4 \mathrm{~h}$ after the AA treatment. 1-g pulp discs of $1 \mathrm{~cm}$ diameter, from the central part of the outer peeled side, were placed on filter paper (Whatman No. 1) soaked with 500 $\mu 10.3 \mathrm{M}$ mannitol in $25 \mathrm{ml}$ conical flasks. The flasks were sealed with rubber serum caps for 15 min at $25^{\circ} \mathrm{C}$. One $\mathrm{ml}$ samples were taken from the headspace and the two volatiles were measured by GC and tested against known standards (Pesis and Frenkel, 1989).

\subsection{Ethylene measurement}

Ethylene production of discs from half-peeled AA-treated and non-treated (control) fruit was determined with and without the application of 1-aminocyclopropane-1-carboxylic acid (ACC). Each day, following AA treatment, five halfpeeled fruits, were taken from AA-treated and control fruit, each fruit being a replicate. From each fruit ten pulp discs were cut from the peeled part, five discs for each flask (duplicates for ACC and + ACC). The discs (1 cm diameter, five discs per gram) were placed on filter paper (Whatman No. 1) soaked with $500 \mu 10.3 \mathrm{M}$ mannitol, with or without $5 \mathrm{mM}$ ACC, in $25 \mathrm{ml}$ conical flasks. Flasks were sealed with serum caps for $1 \mathrm{~h}$ at $17^{\circ} \mathrm{C}$ prior to measuments of headspace ethylene by GC (Pesis and Marinansky, 1992).

\subsection{Sulfhydryl content}

Total SH content was determined by boiling 0.5 $\mathrm{g}$ of pulp in $5 \mathrm{ml}$ of $0.02 \mathrm{M}$ phosphate buffer $(\mathrm{pH}$ 5.7; five samples treatment ${ }^{-1}$ ) for $10 \mathrm{~min}$. After filtration (Millipore $0.45 \mathrm{~mm}$ HA filter), the water-soluble $\mathrm{SH}$ compounds in the mixture were determined spectrophotometrically at $412 \mathrm{~nm}$ with 5,5-dithiobis (2-nitrobenzoic acid) (DTNB) reagent (Ellman, 1959).

\subsection{Protein extraction and enzymes assays}

Lyophylized avocado powder (1 g) was homog-

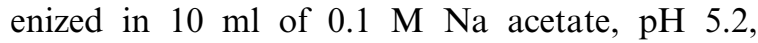
containing $5 \mathrm{mM}$ mercaptoethanol, $0.4 \mathrm{M} \mathrm{NaCl}$, $0.5 \mathrm{mM}$ Phenylmethylsulfonyl fluoride and 10 $\mathrm{mM}$ leupeptin, and then centrifuged at $15000 \times g$ for $30 \mathrm{~min}$. The supernatant was dialyzed against 21 of acetate buffer for $24 \mathrm{~h}$ at $4^{\circ} \mathrm{C}$. Polygalacturonase (PG) activity was determined on sodium polypectate by following the increase in reducing groups (Dori et al. 1995); one unit of PG was defined as the amount of enzyme that liberates 1 $\mu$ mol of reducing groups per min at $30^{\circ} \mathrm{C}$. Endoglucanase $(\mathrm{Cx})$ activity was measured on carboxy methyl cellulose (CMC) by following the increase in reducing groups (Dori et al., 1995); one unit was defined as the amount of enzyme which releases $1 \mu \mathrm{mol}$ glucose per min at $30^{\circ} \mathrm{C}$. $\beta$-galactosidase $(\beta$-GAL) activity was measured with $p$-nitrophenyl- $\beta$-D-galactoside according to Morgenstern et al. (1990); one unit was defined as the amount of enzyme causing a release of $1 \mu \mathrm{mol}$ $p$-nitrophenol $\mathrm{min}^{-1}$.

ACC oxidase was extracted from the same peeled parts used for preparation of discs for ethylene measurements in situ. Extraction and determination of enzyme activity was as described by Fernandez-Maculet and Yang (1992). ACC oxidase activity in vitro was expressed as nl ethylene evolved $\mathrm{mg}^{-1}$ protein $\mathrm{h}^{-1}$. Protein concentration was determined using the Bio-Rad reagent according to Bradford (1976).

\subsection{Electrophoresis}

Electrophoresis and Western blotting were conducted according to the Bio-Rad instruction manual (Bio-Rad M1703930 Rev B). Western blot analysis was performed with total protein extracts from the fruits and was probed with antibodies raised against the conjugate AA-bovine serum albumin (BSA) (kind gift from P. Perata). The primary antibody bands were reacted with commercial goat anti-rabbit secondary antibodies conjugated to alkaline phosphatase (Bio-Rad).

\subsection{Application of $A A$ in vitro}

In order to check the effect of AA on PG activity in vitro, protein was extracted from untreated soft fruit $(10 \mathrm{~N})$ which had high PG activity, and had been held 2 weeks at $17^{\circ} \mathrm{C}$, (Dori et al., 1995). A total of $1 \mathrm{~kg}$ of avocado tissue pulp was extracted in $0.1 \mathrm{M}$ acetate buffer, $\mathrm{pH}$ 
5.2, protein precipitated in saturated ammonium sulfate and left overnight at $4^{\circ} \mathrm{C}$. After centrifugation, the extract was dialyzed against the same buffer for $12 \mathrm{~h}$ at $4^{\circ} \mathrm{C}$. The supernatant was collected after centrifugation for $20 \mathrm{~min}$ at $10000 \times g$, and used as the crude PG solution. The reaction mixture contained a final concentration of 0.95 unit $\mathrm{mg}^{-1}$ protein of $\mathrm{PG}, 0.1 \mathrm{M}$ carbonate buffer $\mathrm{pH} 9.2,0.25 \%$ sodium polypectate, and various concentrations of AA. The mixture was incubated for $0.5 \mathrm{~h}$ at $25^{\circ} \mathrm{C}$ and then a $200 \mathrm{ml}$ sample of the reaction mixture was assayed for reducing sugar (Dori et al., 1995).

Experiments with whole fruits were performed several times during two different years; that with half-peeled fruit was performed twice during the same season. All measurements involved five replicates. Results presented are means \pm S.E.

\section{Results}

Application of AA vapour at increasing concentrations for $24 \mathrm{~h}$, to whole avocado fruits, caused increasing inhibition of fruit ripening. After 11 days storage at $17^{\circ} \mathrm{C}$ this inhibition of ripening was expressed as greater firmness and lower activity of the cell wall degrading enzymes PG and Cx (Fig. 1). The highest AA concentration applied (1500 ppm) maintained fruit firmness at $70 \mathrm{~N}$ and had the lowest PG and $\mathrm{Cx}$ activities

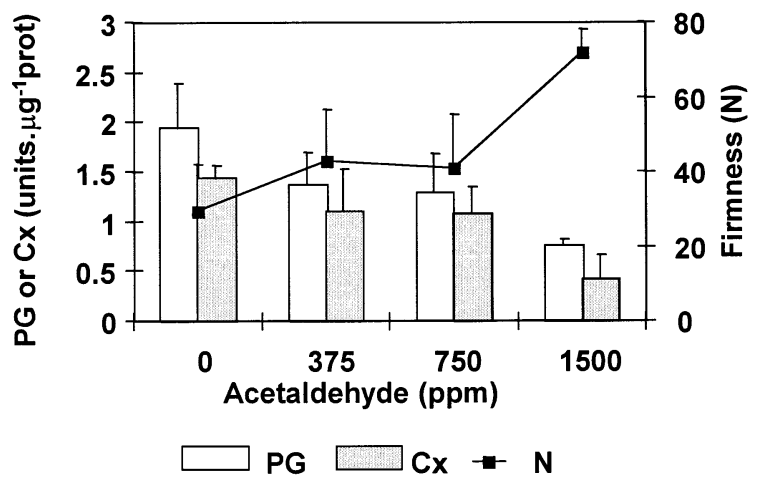

Fig. 1. Effects of various AA vapour concentrations applied for $24 \mathrm{~h}$, on ripening of whole avocado fruit. Fruit firmness (N) and enzyme activity of PG and Cx were measured after 11 days at $17^{\circ} \mathrm{C}$. Data are means of five measurements \pm S.E.

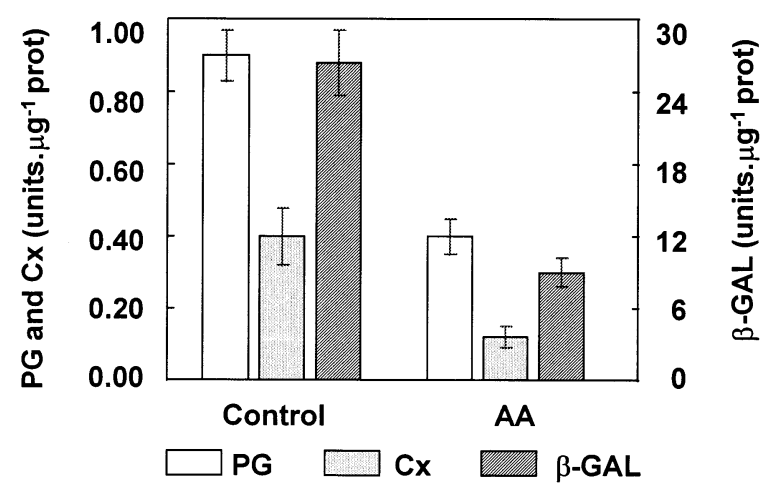

Fig. 2. Effect of AA vapour application for $18 \mathrm{~h}$, on polygalacturonase $(\mathrm{PG})$, endoglucanase $(\mathrm{Cx})$ and $\beta$-galactosidase $(\beta$ GAL) activity of avocado, after 2 days at $17^{\circ} \mathrm{C}$. The enzyme was extracted from the peeled side. Data are means of five measurements \pm S.E.

after 11 days at $17^{\circ} \mathrm{C}$, while control avocados were already soft $(\approx 20 \mathrm{~N})$. Fruits treated with AA concentrations of 500 and 1000 ppm exhibited similar firmness $(40 \mathrm{~N})$ and similar PG and Cx activities (Fig. 1).

Half peeling the fruit surface resulted in rapid softening of the peeled side. Two days after peeling, firmness of the control peeled side was around $40 \mathrm{~N}$, while the control unpeeled side was nearly 2.5 times as firm. This rapid loss of firmness as a result of peeling was completely prevented by AA vapour; firmness of both peeled and unpeeled sides of the AA-treated fruit was similar at about $100 \mathrm{~N}$. The slower decline in fruit firmness in the AA-treated fruits after removal from treatment was associated with decreased activity of the cell-wall-degrading enzymes, PG, $\mathrm{Cx}$ and $\beta$-GAL (Fig. 2). The PG activity was reduced by more than $50 \%$ and the reductions in $\beta-\mathrm{GAL}$ and $\mathrm{Cx}$ activities were even greater (approx. 70\%; Fig. 2).

Inhibition of fruit softening caused by AA treatment lasted for 3 days after treatment (Table 1). In control fruits there was reduction in fruit firmness immediately upon removal from jars and it continued to fall during 4 days at $17^{\circ} \mathrm{C}$, whereas AA-treated fruits maintained firmness around 80 $\mathrm{N} 3$ days after treatment, then 4 days after treatment there was sharp decrease to around $40 \mathrm{~N}$ (Table 1). 
Table 1

Effects of AA vapour on fruit firmness (N) and on the endogenous content of AA and ethanol during 4 days after removal from treatment at $17^{\circ} \mathrm{C}$

\begin{tabular}{llcc}
\hline & Days after treatment at $17^{\circ} \mathrm{C}$ & Control & AA treated \\
\hline Firmness $(\mathrm{N})$ & 1 & $69.4 \pm 4.52$ & $87.4 \pm 7.57$ \\
& 2 & $60.2 \pm 2.06$ & $84.1 \pm 2.94$ \\
& 3 & $49.1 \pm 3.87$ & $75.7 \pm 2.81$ \\
& 4 & $29.2 \pm 1.57$ & $42.1 \pm 4.60$ \\
Acetaldehyde $\left(\mu \mathrm{g} \mathrm{g}^{-1} \mathrm{FW}\right)$ & 1 & $0.76 \pm 0.32$ & $13.23 \pm 0.65$ \\
& 2 & $0.17 \pm 0.10$ & $8.01 \pm 0.91$ \\
& 3 & $0.22 \pm 0.05$ & $4.28 \pm 1.75$ \\
Ethanol $\left(\mu \mathrm{g} \mathrm{g}^{-1} \mathrm{FW}\right)$ & 4 & $0.03 \pm 0.03$ & $0.47 \pm 0.19$ \\
& 1 & $7.21 \pm 0.38$ & $201.1 \pm 9.98$ \\
& 2 & $3.10 \pm 0.22$ & $197.1 \pm 20.21$ \\
& 3 & $7.73 \pm 0.63$ & $30.7 \pm 8.53$ \\
\end{tabular}

The firmness and the volatile contents were measured daily on the peeled side of control and AA-treated avocado fruits. Day 1 measurements were taken after $4 \mathrm{~h}$ of air ventilation following $18 \mathrm{~h}$ of AA treatment. Data are means of five measurements \pm S.E.

Endogenous concentrations of AA and ethanol in avocado discs from the peeled side of AAtreated fruits were relatively low compared with the high concentrations applied (Table 1). On the first day, after $4 \mathrm{~h}$ of air ventilation, AA concentration was quite low $\left(13.23 \mu \mathrm{g} \mathrm{g}^{-1}\right)$, but ethanol was 15 times higher $\left(201 \mu \mathrm{g} \mathrm{g}^{-1}\right)$. During the next 3 days concentrations of AA and ethanol fell dramatically (Table 1); in control fruits, which were half peeled and flushed with air, endogenous concentrations of AA and ethanol were much lower than those in AA-treated fruits in the first 2 days after treatment. However, differences progressively diminished 3 and 4 days after treatment (Table 1).

Ethylene production in peeled control fruits reached a climacteric peak on the second day after peeling, while AA-treated fruits produced very little ethylene. Only after 4 days at $17^{\circ} \mathrm{C}$ did ethylene production in the AA-treated fruits start to increase (Fig. 3A). Addition of ACC, the immediate precursor of ethylene, did not cause a significant increase in ethylene production in either treated or control fruits (Fig. 3A).

The same half-peeled fruits from which discs were cut for the in situ ethylene determination were extracted for measurements of ACC oxidase in vitro. ACC oxidase increased to a maximum after $2-3$ days at $17^{\circ} \mathrm{C}$ in control fruit but there was very little activity in AA-treated fruits (Fig. 3B). Inhibition of enzyme activity in vitro by AA vapour was correlated with the inhibition of ethylene production in situ (Fig. 3).

Fruit pulp oxidation was inhibited following AA treatment. After 4 days at $17^{\circ} \mathrm{C}$, half-peeled control fruit oxidized completely and the green pulp became black, while half-peeled AA-treated fruit remained green (Fig. 4).

Total content of free sulfhydryl (SH) groups, measured in pulp from the peeled part, increased within 2 days in AA-treated fruits remaining constant during 4 days at $17^{\circ} \mathrm{C}$, while in control fruits it fluctuated but remained significantly lower than in the AA-treated fruit (Fig. 5). The fluctuation in levels of free $\mathrm{SH}$ groups in control fruit was probably because extraction was from different fruits on each day.

Attempts were made to see if AA could interact directly with protein extracted from the fruit. In vitro experiments showed a gradual inhibition of crude PG activity by direct application of increasing amounts of $\mathrm{AA}$ in the reaction mixture: the highest AA concentration (1.5\%) inhibited PG activity by approx. $50 \%$ (Table 2 ). Pre-incubation of pectin or sodium polypectate with AA did not result in inhibition of PG activity. 
Attempts to detect AA bound to protein in AA-treated avocado by western blotting with antibodies raised against the conjugate BSA-AA gave negative results.

\section{Discussion}

Even though AA is an anaerobic metabolite, when applied in air its effects in inhibiting fruitripening processes were similar to those obtained under anaerobiosis (Lurie and Pesis, 1992; Pesis and Marinansky, 1993; Pesis et al., 1994). Acetaldehyde has previously been shown to inhibit softening in peach and tomato (Lurie and Pesis, 1992; Pesis and Marinansky, 1993; Beaulieu et al., 1997). The inhibition of avocado softening by AA vapour is similar to that caused by low $\mathrm{O}_{2}$ treatment (Pesis et al., 1994) or by ethanol vapour
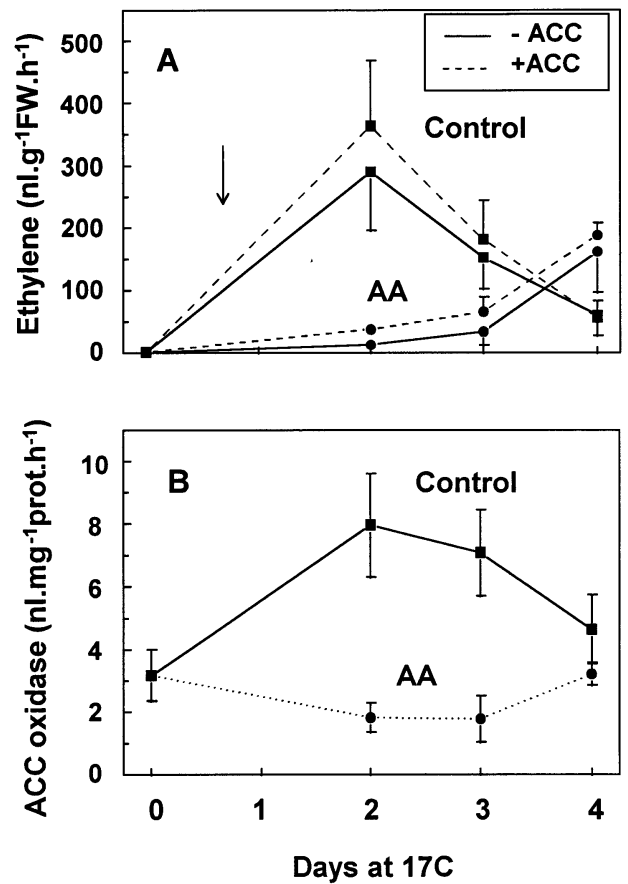

Fig. 3. Effect of AA vapour application for $18 \mathrm{~h}$, on ethylene production of avocado discs in vivo, with and without addition of ACC (A), and on ACC oxidase activity in vitro (B) during 4 days at $17^{\circ} \mathrm{C}$. Discs and enzyme extraction were from the peeled side taken at daily intervals. Arrow indicates removal from treatment. Data are means of five measurements \pm S.E.

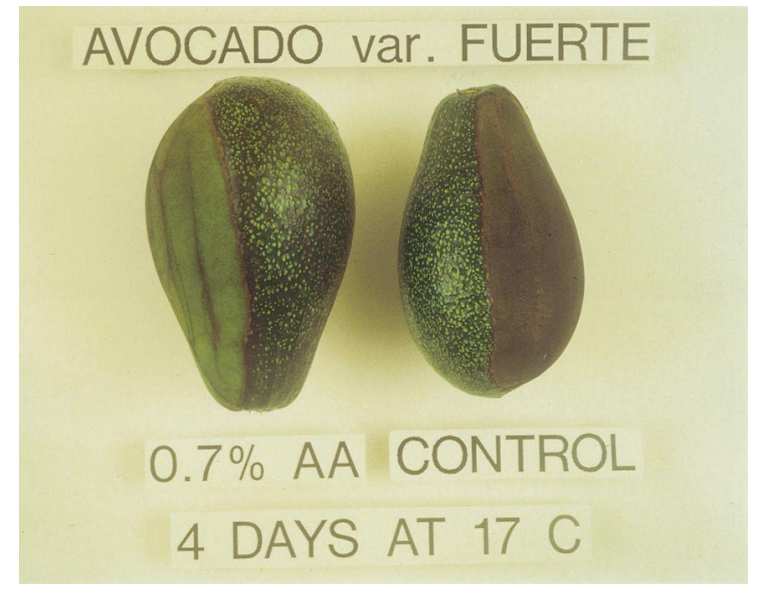

Fig. 4. Effect of AA vapour application for $18 \mathrm{~h}$ (initially $0.7 \%$ ), on darkening of half-peeled avocado fruit. The picture was taken after 4 days at $17^{\circ} \mathrm{C}$.

(Dori et al., 1995; Ritenour et al., 1997). However, it is known that ethanol acts via AA; by using a specific alcohol dehydrogenase (ADH) inhibitor, 4-methylpyrazole, AA has been shown to be the active agent inducing the effects of ethanol in carrot cells (Perata and Alpi, 1991) and tomato discs (Beaulieu et al., 1997).

Inhibition of softening in avocado fruit was correlated with inhibition in activities of three cell wall degrading enzymes. (Figs. 1 and 2). A similar inhibition in PG activity by pretreatment with AA or a low $\mathrm{O}_{2}$ atmosphere was found in peaches

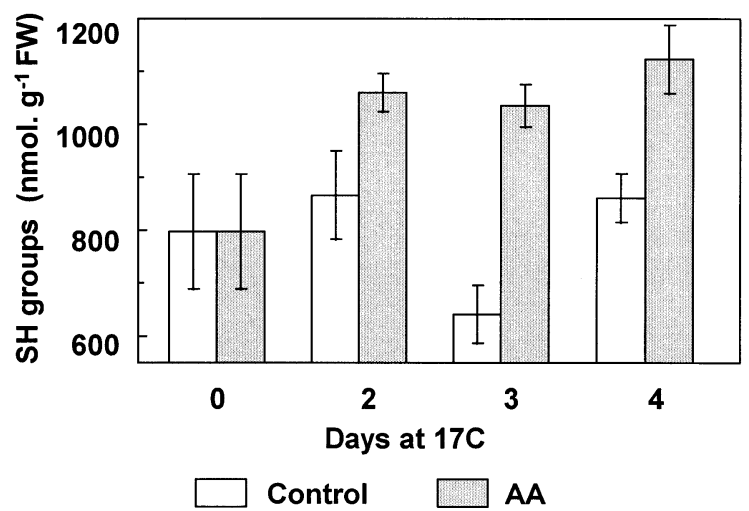

Fig. 5. Effect of AA vapour application for $18 \mathrm{~h}$, on total content of free $\mathrm{SH}$ group compounds during 4 days at $17^{\circ} \mathrm{C}$. $\mathrm{SH}$ extraction was from the peeled side taken at daily intervals. Data are means of five measurements \pm S.E. 
Table 2

Effects of various AA concentrations added to the reaction mixture on in vitro inhibition of polygalacturonase (PG) activity extracted from untreated soft avocado

\begin{tabular}{llc}
\hline $\begin{array}{l}\text { AA concentration } \\
(\%)\end{array}$ & $\begin{array}{l}\text { PG activity } \\
\text { (units } \mu \mathrm{g}^{-1} \text { protein) }\end{array}$ & $\begin{array}{l}\text { Relative PG } \\
\text { activity (\%) }\end{array}$ \\
\hline 0.0 & $2.50 \pm 0.18$ & $100 \pm 7.4$ \\
0.5 & $1.77 \pm 0.20$ & $71 \pm 8.1$ \\
1.0 & $1.85 \pm 0.38$ & $74 \pm 15.2$ \\
1.5 & $1.30 \pm 0.09$ & $52 \pm 3.9$ \\
\hline
\end{tabular}

Data are means of five measurements \pm S.E.

(Lurie and Pesis, 1992) and tomatoes (Pesis and Marinansky, 1993). Kanellis et al. (1991) demonstrated suppression of $\mathrm{PG}$ and $\mathrm{Cx}$ isoenzyme activities in avocado fruit under continuous low $\mathrm{O}_{2}$ atmospheres. However, reduction in $\mathrm{PG}$ and $\mathrm{Cx}$ activities in stored avocado after 7 days has also been achieved by a short pre-storage treatment with ethanol or low $\mathrm{O}_{2}$ (Dori et al., 1995). The enzyme $\beta$-Gal was found to play a major part in enzymic softening of avocado (De Veau et al., 1993). In the present work we show that the activities of all three enzymes were inhibited to similar extent by AA vapour.

The enhanced levels of endogenous ethanol found in the AA-treated avocado (Table 1), suggest that there is a rapid conversion of AA to ethanol by the enzyme ADH. Rapid metabolism of AA in fruit flesh, after AA application, occurs in several other fruits, including grape and tomato; in all of these, ethanol concentrations were much higher than those of AA, probably because AA is an intermediate while ethanol is an end-product in anaerobic metabolism (Pesis and Frenkel, 1989; Pesis and Marinansky, 1993).

The rapid increase in ethylene production in peeled untreated avocado fruit was probably due to peeling, since wounding is known to accelerate ethylene synthesis and subsequent ripening (Starrett and Laties, 1991). However, AA application significantly delayed ethylene production (Fig. 3A). Addition of exogenous ACC did not greatly increase ethylene production in untreated fruit, which indicates that there was enough endogenous ACC in the peeled avocado fruit to maintain ethylene production. In mango fruit, addition of
ACC caused a ten-fold increase in ethylene production in control peeled fruit, but as in these experiments with avocado, ethylene production in AA-treated peeled mango was inhibited even in the presence of ACC (Burdon et al., 1996). Similarly, in halved grapes (a non-climacteric fruit) supplied with ACC, AA reduced ethylene production (Pesis and Marinansky, 1992). In both grape and mango, application of ethanol, at the same concentration as that of AA, was not effective in inhibiting ethylene production in situ (Pesis and Marinansky, 1992; Burdon et al., 1996).

In avocado, inhibition of ethylene by AA was also found in vitro (Fig. 3B), which probably indicates that AA vapour inhibits ACC oxidase activity in vivo and in vitro. ACC oxidase includes 28 lysine residues out of 314 amino acids (Dong et al., 1992), and these free $\mathrm{NH}_{2}$ residues could probably interact with the AA molecule and affect ACC oxidase activity. In animal tissue it has been shown that AA binds to the free amino groups of proteins, particularly the $\alpha$ amino groups at the $\mathrm{NH}_{2}$-termini and the $\varepsilon$ amino groups of internal lysyl residues (Mauch et al., 1986; Jennett et al., 1987)

Avocado pulp is rich in polyphenol oxidase, an enzyme that causes immediate oxidation and blackening of tissue exposed to oxygen (Kahn, 1975). We found that when the pulp surface is exposed to air it is oxidized and becomes brown (Fig. 4). As in mango discs or peeled areas, the natural progressive browning of these surfaces with time after preparation was retarded by application of AA (Burdon et al., 1996), probably through inhibition of the activity of the oxidizing enzymes.

SH compounds are reducing molecules that play an important role in regulating senescence processes, involving a progressive shift from a reduced to an oxidized state (Jocelyn, 1972). Avocados treated with low $\mathrm{O}_{2}$ prior to storage at $2{ }^{\circ} \mathrm{C}$, exhibited reduced ethylene production and reduced chilling injury symptoms, as well as higher concentrations of free $\mathrm{SH}$ groups in the peel and the pulp than did control fruit (Pesis et al., 1994). In the present work, higher concentrations of free $\mathrm{SH}$ groups were found in pulp of AA-treated fruits than in controls (Fig. 5). Initial 
levels of free $\mathrm{SH}$ groups in the avocado pulp were relatively high $\left(800 \mathrm{nmol}^{-1}\right)$, probably because those specific fruits were harvested at the end of the season, whereas in fruit harvested at the beginning of the season, initial levels were almost zero (Pesis et al., 1994). An increase in glutathione levels during maturity occurs in grape berries (Adams and Liyanage, 1993), and in tomato and mango fruits concentrations of free $\mathrm{SH}$ groups have been found to increase during maturation (Tabachnik-Ma'ayan and Fuchs, 1982). The increase in $\mathrm{SH}$ groups upon removal from AA treatment is similar to that obtained with rice seedlings removed from anaerobiosis; during adaptation of submerged tissue to air an increase in reduced forms of ascorbate and glutathione has been found (Ushimaru et al., 1992). It is possible that in AA-treated avocados the higher levels of SH group compounds maintained tissue in a less oxidized form, because of inhibition of oxidizing enzyme activity by AA vapour.

Although addition of AA to the enzyme mixture reduced PG activity in vitro (Table 2), it is not clear whether the AA changed the PG protein or just interferred with the reaction. The possibility that AA reacted directly with the $\mathrm{PG}$ protein cannot be excluded. It is well established that AA has two highly reactive pairs of electrons which have the potential to form covalent bonds to amino groups (Mauch et al., 1986). In other in vitro studies, AA formed adducts with various mammalian proteins such as tubulin, ribonuclease and BSA (Mauch et al., 1986; Jennett et al., 1987; Perata et al., 1992).

Our failure to detect AA bound to protein in the AA-treated avocado, in spite a very high concentration of AA applied, was similar to results obtained by Perata et al. (1992), who did not find endogenously reduced stable AA adducts to protein in ethanol-treated carrot cells in vivo. In mammalian studies, antibodies against AAprotein conjugates, but not the AA-protein adducts themselves, were found only in the blood of ethanol-treated animals, suggesting that these adducts are produced in vivo and can act as neoantigens (Worral et al., 1989).

\section{Acknowledgements}

We express our appreciation to Joshua D. Klein for his critical review of the manuscript. Contribution from the Agricultural Research Organization, The Volcani Center, Bet Dagan, Israel. No. 2294-E, 1997 series.

\section{References}

Adams, D.O., Liyanage, C., 1993. Glutathione increase in grape berries at the onset of ripening. Am. J. Enol. Vitic. 44, 333-338.

Beaulieu, J.C., Peiser, G., Saltveit, M., 1997. Acetaldehyde is a causal agent responsible for ethanol-induced ripening inhibition in tomato fruit. Plant Physiol. 113, 431-439.

Bio-Rad Immun-Blot Assay Kit Instruction Manual. M1703930 Rev B.

Bradford, M.M., 1976. A rapid and sensitive method for quantitation of microgram quantities of protein utilizing the principle of protein-dye binding. Anal. Biochem. 72, $248-254$.

Burdon, J.N., Dori, S., Lomaniec, E., Marinansky, R., Pesis, E., 1994. Effect of pre-storage treatments on mango fruit ripening. Ann. Appl. Biol. 125, 581-587.

Burdon, J.N., Dori, S., Marinansky, R., Pesis, E., 1996. Acetaldehyde inhibition of ethylene biosynthesis in mango fruit. Postharvest Biol. Tech. 8, 153-161.

De Veau, E.J.I., Gross, K.C., Huber, D.J., Watada, A.E., 1993. Degradation and solubilization of pectin by $\beta$-galactosidases purified from avocado fruit. Physiol. Plant. 87, $279-285$.

Dong, J.G., Fernandez-Maculet, J.C., Yang, S.F., 1992. Purification and characterization of 1-aminocyclopropane-1-carboxylate oxidase from apple fruit. Proc. Natl. Acad. Sci. U.S.A. 89, 9789-9793.

Dori, S., Burdon, J.N., Lomaniec, E., Pesis, E., 1995. Effect of anaerobiosis on aspects of avocado fruit ripening. Acta Hort. 379, 129-136.

Ellman, G.L., 1959. Tissue sulfhydryl groups. Arch. Biochem. Biophys. 82, 70-77.

Fernandez-Maculet, J.C., Yang, S.F., 1992. Extraction and partial characterisation of the ethylene-forming enzyme from apple fruit. Plant Physiol. 99, 751-754.

Fidler, P.C., 1968. The metabolism of acetaldehyde by plant tissues. J. Exp. Bot. 19, 41-51.

Jennett, R.B., Sorrell, M.F., Johnson, E.L., Tuma, D.J., 1987. Covalent binding of acetaldehyde to tubulin. Evidence for preferential binding to the $\alpha$-chain. Arch. Biochem. Biophys. 256, 10-18.

Jocelyn, P.C., 1972. Biochemistry of the SH Group. Academic Press, London, pp. 82-84.

Kahn, V., 1975. Polyphenol oxidase activity and browning of three avocado varieties. J. Sci. Food Agric. 26, 1319-1324. 
Kanellis, A.K., Solomos, T., Roubelakis-Angelakis, K.A., 1991. Suppression of cellulase and polygalacturonase and induction of alcohol dehydrogenase isoenzymes in avocado fruit mesocarp subjected to low oxygen stress. Plant Physiol. 96, 269-274.

Lurie, S., Pesis, E., 1992. Effect of acetaldehyde and anaerobiosis as postharvest treatments on the quality of peaches and nectarines. Postharvest Biol. Technol. 1, 317-326.

Mauch, T.J., Donohue, T.M., Zetterman, R.K., Sorrel, M.F., Tuma, D.J., 1986. Covalent binding of acetaldehyde selectively inhibits the catalytic activity of lysine-dependent enzymes. Hepatology 6, 263-269.

Morgenstern, E., Bayer, A., Lamed, R., 1990. Relationship of cellulosomal and noncellulosomal xylanases of Clostridum thermocellum to cellulose degrading enzymes. J. Bacteriol. 172, 6098-6105.

Perata, P., Alpi, A., 1991. Ethanol induced injuries to carrot cells. The role of acetaldehyde. Plant Physiol. 95, 748-752.

Perata, P., Vernieri, P., Armellini, D., Bugnoli, M., Tognoni, F., Alpi, A., 1992. Immunological detection of acetaldehyde-protein adducts in ethanol-treated carrot cells. Plant Physiol. 98, 913-918.

Pesis, E., Frenkel, C., 1989. Effects of acetaldehyde vapours on postharvest quality of table grapes. HortScience 24, 315-317.
Pesis, E., Marinansky, R., 1992. Carbon dioxide and ethylene production in response to acetaldehyde and ethanol treatments in grapes. J. Am. Soc. Hort. Sci. 117, 110-113.

Pesis, E., Marinansky, R., 1993. Inhibition of tomato ripening by acetaldehyde vapour or anaerobic conditions prior to storage. J. Plant Physiol. 142, 717-721.

Pesis, E., Marinansky, R., Zauberman, G., Fuchs, Y., 1994. Prestorage low oxygen atmosphere treatment reduces chilling injuries in avocado fruit. HortScience 29, 1042-1046.

Ritenour, M.A., Mangrich, M.E., Beaulieu, J.C., Rab, A., Saltveit, M.A., 1997. Ethanol effects on the ripening of climacteric fruit. Postharvest Biol. Technol. 12, 35-42.

Starrett, D.A., Laties, G.G., 1991. Involvement of wound and climacteric ethylene in ripening avocado discs. Plant Physiol. 97, 720-729.

Tabachnik-Ma'ayan, L., Fuchs, Y., 1982. Free sulfhydryl groups in ripening fruits. Plant Cell Physiol. 23, 13091314.

Ushimaru, T., Shibasaka, M., Tsuji, H., 1992. Development of the $\mathrm{O}_{2}$ detoxification system during adaptation to air of submerged rice seedlings. Plant Cell Physiol. 33, 10651071.

Worral, S., De Jersey, J., Shanley, B.C., Wilce, P.A., 1989. Ethanol induces the production of antibodies to acetaldehyde-modified epitopes in rats. Alcohol Alcohol. 24, $217-$ 223. 